\title{
\begin{tabular}{l|l|l} 
Jurnal Kependidikan Dasar & $\begin{array}{l}\text { Volume : } 2 \\
\text { Nomor : } 2\end{array}$ \\
Tahun : $: 2017$
\end{tabular}
}

\section{Penerapan Model Pembelajaran Problem Based Learning (PBL) untuk Meningkatkan Hasil Belajar IPA Pada Siswa Kelas IV SDN Kertosari I Kabupaten Madiun}

\author{
Naniek Kusumawati \\ Dosen Prodi PGSD Universitas PGRI Madiun \\ Surel : naniek@unipma.ac.id
}

\begin{abstract}
ABSTRAK
Penelitian ini menggunakan pendekatan deskriptif kualitatif. Subjek dalam penelitian ini yaitu siswa kelas IV SDN Kertosari I Kabupaten Madiun sejumlah 20 siswa. Jenis penelitian yang digunakan adalah penelitian tindakan kelas dengan teknik pengumpulan data melalui observasi, wawancara, dan dokumentasi. Teknik analisis data menggunakan Triangulasi serta kegiatan pengumpulan data menggunakan siklus yang terdiri dari 2 siklus. Peningkatan hasil belajar siswa dengan aspek kemampuan siswa dalam memecahkan masalah, kemampuan siswa dalam melakukan percobaan, kerjasama dalam kelompok. Ketuntasan hasil belajar siswa pada pra siklus yaitu 25\%, siklus I adalah $65 \%$ dan siklus II mencapai 90\%. Kesimpulan dari hasil penelitian menunjukkan bahwa materi perubahan lingkungan dengan menggunakan model pembelajaran Problem Based Learning (PBL) dapat meningkatkan hasil belajar IPA pada siswa kelas IV SDN Kertosari I Kabupaten Madiun Tahun Pelajaran 2016/2017.
\end{abstract}

Kata Kunci: Model Problem Based Learning, Hasil Belajar IPA

\section{ABSTRACT}

This study used a qualitative descriptive approach. Subjects in this study are students of class IV SDN Kertosari I District Madiun number of 20 students. This type of research is a classroom action research technique of collecting data through observation, interviews, and documentation. Data were analyzed using triangulation and data collection activities using cycles consisting of 2 cycles. Improving student learning outcomes with aspects of the student's ability to solve problems, the ability of students to conduct experiments, cooperation within the group. The completeness of student learning outcomes in cycle pra is 25\%, the first cycle is $65 \%$ and cycle II reached 90\%. The ability of the students in the trials experienced improvement from the first cycle to the second cycle and demonstrate mastery. Conclusions from the study indicate that the material changes in the environment by using model Problem Based Learning (PBL) can improve learning outcomes in grade IV IPA SDN Kertosari I District Madiun School Year 2016/2017.

Keywords: Model Problem Based Learning, Science Learning Outcomes 


\section{A. PENDAHULUAN}

Berkaitan dengan pembelajaran Ilmu Pengetahuan Alam (IPA), Susanto ${ }^{1}$ mengemukakan bahwa, "IPA mata pelajaran yang selama ini dianggap sulit oleh sebagian besar peserta didik, mulai dari jenjang sekolah dasar sampai sekolah menengah". Anggapan sebagian besar peserta didik yang menyatakan bahwa pelajaran IPA sulit dapat dilihat dari hasil perolehan Ujian Akhir Sekolah (UAS) yang dilaporkan oleh Depdiknas masih kurang dari standar yang diharapkan. Salah satu masalah yang dihadapi dunia pendidikan saat ini adalah masalah lemahnya pelaksanaan proses pembelajaran yang diterapkan pada guru disekolah. Proses pembelajaran yang terjadi selama ini kurang mampu mengembangkan kemampuan berfikir peserta didik. Berdasarkan hasil observasi guru kelas IV di SDN Kertosari I Kabupaten Madiun, diperoleh data nilai tahun pelajaran 2016/2017 pada pembelajaran IPA. Hal tersebut terlihat bahwa dari jumlah siswa kelas IV sebanyak 20 siswa dan yang berhasil mencapai KKM (>70) adalah 5 siswa (25\%) yang tidak tuntas 15 siswa (75 \%). Dari data tersebut, dapat diketahui bahwa siswa belum mampu menerima dan memahami materi secara maksimal.

Berdasarkan persoalan di atas salah satu upaya yang dapat dilakukan untuk meningkatkan kualitas pembelajaran yaitu dengan menerapkan

\footnotetext{
${ }^{1}$ Ahmad Susanto, Teori Belajar Dan Pembelajaran Di Sekolah Dasar (Jakarta: Kencana Prenada Media Group, 2013), 168.
}

model pembelajaran yang sesuai dengan materi dan kondisi lingkungan sekitar. Model yang cocok diterapkan dalam mengatasi persoalan tersebut yaitu model Problem Based Learning (PBL). Rusman ${ }^{2}$ menerangkan "kurikulum PBL memfasilitasi keberhasilan memecahkan masalah, komunikasi, kerja kelompok dan keterampilan interpersonal dengan lebih baik dibanding dengan pendekatan yang lain". Berdasarkan latar belakang yang telah dipaparkan, peneliti akan melakukan penelitian dengan judul "Penerapan Model Pembelajaran Problem Based Learning untuk Meningkatkan Hasil Belajar IPA pada Siswa Kelas IV SDN Kertosari I Kabupaten Madiun".

\section{B. KAJIAN PUSTAKA}

Pembelajaran didasarkan pada pengalaman untuk membantu siswa belajar, mendeskripsikan dan menjelaskan hasil kerja dan prosedurnya. Proses belajar ditandai dengan adanya perubahan pada individu yang belajar, baik berupa sikap, perilaku, pengetahuan, pola pikir, dan konsep nilai yang dianut. Sebagaimana dikemukakan Susanto ${ }^{3}$ bahwa "IPA adalah usaha manusia dalam memahami alam semesta melalui pengamatan yang tepat pada sasaran, serta menggunakan prosedur, dan dijelaskan dengan penalaran sehingga

\footnotetext{
${ }^{2}$ Rusman, Model-Model Pembelajaran Mengembangkan Profesionalisme Guru (Jakarta: Raja Grafindo Persada, 2010), 230.

3 Susanto, Teori Belajar Dan Pembelajaran Di Sekolah Dasar, 167.
} 
mendapatkan suatu kesimpulan". Jadi dalam pembelajaran IPA disekolah dasar tidak hanya belajar tentang alam semesta saja tetapi untuk mengembangkan pemikiran manusia dalam memahami konsep IPA. Menurut Kusumawati ${ }^{4}$, salah satu permasalahan yang terdapat dalam proses pembelajaran IPA saat ini adalah lemahnya proses pembelajaran. Proses pembelajaran di dalam kelas lebih banyak diarahkan kepada siswa untuk menghafal informasi tanpa dituntut untuk memahami dan mengembangkan informasi yang diingat dalam kehidupan sehari-hari.

Berdasarkan

proses pembelajaran IPA belajar bukanlah sesuatu yang baru, sudah sangat dikenal secara luas. Sebagaimana dikemukakan oleh Slameto bahwa "belajar adalah suatu proses usaha yang dilakukan seseorang untuk memperoleh suatu perubahan tingkah laku yang baru secara keseluruhan, sebagai hasil pengalamannya sendiri dalam interaksi dengan lingkungannya". ${ }^{5}$ Hasil belajar seringkali digunakan sebagai ukuran untuk mengetahui seberapa jauh seseorang mengetahui atau menguasai bahan yang sudah diajarkan. Seperti pendapat Sudjana "Hasil belajar adalah

\footnotetext{
${ }^{4}$ Naniek Kusumawati, “PENGEMBANGAN MEDIA PEMBELAJARAN IPA DENGAN ANIMASI MACROMEDIA FLASH BERBASIS MODEL PENGAJARAN LANGSUNG (DIRECT INSTRUCTION) DI SEKOLAH DASAR," Premiere Educandum: Jurnal Pendidikan Dasar Dan Pembelajaran 5, no. 02 (2016).

${ }^{5}$ Slameto, Belajar Dan Faktor-Faktor Yang Mempengaruhinya (Jakarta: Rineka Cipta, 1988).
}

kemampuan-kemampuan yang dimiliki siswa setelah ia menerima pengalaman belajarnya". ${ }^{6}$ Menurut Susanto, Hasil belajar merupakan perubahan-perubahan yang terjadi pada diri siswa, baik yang menyangkut aspek kognitif, afektif, dan psikomotor sebagai hasil dari kegiatan belajar. ${ }^{7}$ Berdasarkan uraian tersebut bahwa seseorang yang memiliki pengalaman baru dan dikembangkan merupakan proses dari hasil belajar. Selain itu, perubahan yang nampak pada siswa baik tingkah laku, maupun kemampuan yang dimiliki siswa merupakan proses dari hasil belajar siswa.

Model pembelajaran meliputi suatu model pembelajaran yang luas dan menyeluruh. Oleh sebab itu model pembelajaran digunakan sebagai suatu konsep yang membantu menjelaskan proses pembelajaran baik dalam menjelaskan pola pikir maupun pola tindakan pembelajaran. Sebagaimana dikemukakan Suprijono bahwa "model pembelajaran ialah pola yang digunakan sebagai pedoman dalam merencanakan pembelajaran di kelas maupun tutorial". ${ }^{8}$ Hal yang perlu diperhatikan dalam pemilihan model pembelajaran meliputi pendekatan suatu model pembelajaran yang luas dan menyeluruh. Salah satu model yang tepat adalah model Problem

\footnotetext{
${ }^{6}$ Nana Sudjana, Penilaian Hasil Proses Belajar Mengajar (Remaja Rosdakarya, 1990), 22.

${ }^{7}$ Susanto, Teori Belajar Dan Pembelajaran Di Sekolah Dasar, 5.

${ }^{8}$ Agus Suprijono, Cooperative Learning (Yogyakarta: Pustaka Pelajar, 2011), 46.
} 
Based Learning. Hal itu sesuai dengan pendapat Sutirman bahwa "Model Pembelajaran Problem Based Learning adalah proses pembelajaran yang menggunakan pendekatan siswa memecahkan masalah atau menghadapi tantangan yang akan diperlukan dalam kehidupan nyata". ${ }^{9}$ Berdasarkan uraian tersebut model pembelajaran berbasis masalah merupakan model pembelajaran yang berangkat dari masalah hingga sampai menemukan solusinya.

$$
\text { Adapun langkah-langkah }
$$
penerapan model Problem Based Learning dalam pembelajaran IPA sebagai berikut: (a) orientasi pada masalah kegiatannya; menjelaskan tujuan pembelajaran, menjelaskan materi pembelajaran, guru memberikan sebuah masalah kepada siswa untuk didiskusikan dengan kelompoknya; (b) mengorganisasikan siswa untuk belajar, kegiatannya antara lain; guru memotivasi siswa dalam pembelajaran, guru membagi siswa kedalam kelompok, guru membimbing siswa untuk mendefinisikan tugas yang berhubungan dengan masalah; (c) membantu penyelidikan secara mandiri dan kelomppok, kegiatannya antara lain; guru mengarahkan siswa untuk mencari informasi dari sumber lain, guru membimbing siswa untuk berdiskusi, guru membimbing siswa untuk melakukan percobaan secara individu maupun berkelompok; (d) pada langkah analisis dan evalusi kegiatannya antara lain; guru membimbing sswa untuk menyiapkan hasil karyanya, perwakilan

\footnotetext{
${ }^{9}$ Sutirman, Media Dan Model-Model Pembelajaran Inovatif (Yogyakarta: Graha IImu, 2013).
}

kelompok mempresentasikan hasil diskusinya, guru bersama siswa menganalisis dan mengevaluasi hasil karyanya.

\section{METODE PENELITIAN}

Penelitian ini dilaksanakan di kelas IV SDN Kertosari I Kabupaten Madiun. Penelitian ini dilaksanakan pada bulan Maret sampai dengan Juli 2016. Penelitian ini menggunakan Penelitian Tindakan Kelas (PTK) sedangkan jenis penelitiannya adalah kualitatif. Bentuk penelitian ini termasuk penelitian tindakan kelas kolaboratif dalam pelaksanaan penelitian, peneliti sebagai guru kelas dibantu oleh observer yang berfungsi sebagai pengamat yaitu guru kelas IV. Arikunto dkk menjelaskan " Penelitian Tindakan Kelas (PTK) merupakan suatu pencermatan terhadap kegiatan belajar berupa sebuah tindakan, yang sengaja dimuncukan dan terjadi dalam sebuah kelas secara bersamaan". ${ }^{10}$ Menurut Arikunto,dkk mengumukakan model penelitian tindakan terdapat empat langkah yang harus dilalui yaitu perencanaan (Planning), pelaksanaan Tindakan (Acting), Pengamatan (Observing) dan refleksi (Reflecting). Arikunto mengumukakan model penelitian tindakan ada 4 tahapan yang dilalui yaitu (1) perencanaan, (2) pelaksanaan, (3) pengamatan, dan (4) refleksi. ${ }^{11}$ Adapun model dan penjelasan untuk masing- masing tahap adalah sebagai berikut:

\footnotetext{
${ }^{10}$ Suharsimi Arikunto, Prosedur Penelitian Suatu Pendekatan Praktek (Jakarta: Rineka Cipta, 2006), 3.

${ }^{11}$ Arikunto, 16.
} 


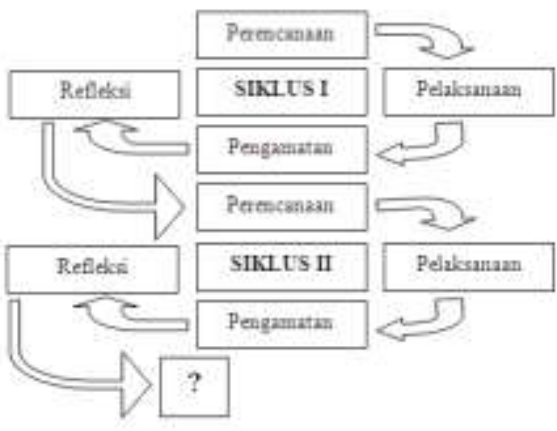

Gambar. 1 Tahapan Siklus

Subjek dalam penelitian ini adalah guru dan siswa kelas IV yang berjumlah 20 siswa terdiri dari 11 siswa laki-laki dan 9 siswa perempuan. Teknik pengumpulan data yang digunakan dalam Penelitian Tindakan Kelas menggunakan observasi, wawancara dan dokumentasi. Sedangkan teknik analisis datanya menggunakan triangulasi.

\section{HASIL PENELITIAN DAN PEMBAHASAN}

Pada pembahasan ini akan dibahas tentang hasil penelitian dan hasil temuan yang diperoleh peneliti ketika mengadakan penelitian. Pembahasan pada siklus I dan siklus II disesuaikan dengan pola pembahasan yang telah diatur berdasarkan menjawab dari rumusan masalah. Berdasarkan analisis data yang diperoleh peneliti dalam melakukan peningkatan hasil belajar IPA melalui model pembelajaran Problem Based Learning (PBL) pada siswa kelas IV SDN Kertosari I Kabupaten Madiun dapat diambil kesimpulan bahwa hasil penelitian yang diperoleh menunjukkan bahwa penelitian yang dilakukan sudah berjalan dengan baik adanya peningkatan pada hasil belajar siswa kelas IV yang dilakukan dengan menggunakan model pembelajaran Problem Based Learning $(P B L)$.

Pernyatan ini didukung oleh hasil analisis data secara triangulasi data observasi, wawancara dan dokumentasi. Keberhasilan penelitian ini dapat dilihat dari semua indikator keberhasilan yang menjadi tolak ukur keberhasilan penelitian sudah tercapai. Hasil nilai awal belum memenuhi KKM yang ditentukan, yaitu dari 20 siswa terdapat 15 anak atau $25 \%$ yang belum mencapai KKM pada pelajaran IPA materi Perubahan Lingkungan. Nilai tersebut belum memenuhi nilai rata-rata yang ditentukan yaitu sebesar $\geq 70$. Kegiatan pembelajaran yang selama ini diterapkan di kelas lebih banyak menggunakan metode ceramah, sehingga kurang melibatkan siswa secara langsung dalam pembelajaran. Hal ini menegaskan masih dibutuhkan perbaikan dalam proses pembelajaran sehingga hasil belajar dapat mencapai batas ketuntasan SDN Kertosari I Kabupaten Madiun.

Setelah menganalisis masalah yang ada, diketahui kesulitan siswa dalam proses pembelajaran selama ini diantara lain masih kurangnya tingkat pemahaman dalam memahami materi dan keaktifan siswa. model pembelajaran Problem Based Learning yang dialami oleh siswa yaitu dengan cara siswa dapat termotivasi dan terbantu dalam memahami Perubahan Lingkungan. Namun dalam siklus I masih ada siswa yang belum bisa aktif dalam proses pembelajaran dan kurangnya tingkat pemahaman dalam memahami materi Perubahan Lingkungan. Dalam kegiatan 
ini siswa terlihat kesulitan untuk berpartisipasi dalam proses pembelajaran serta kesulitan dalam memahami pembelajaran. Untuk mengatasi kekurangan model pembelajaran Problem Based Learning pada siklus I, maka guru mengevaluasikan kepada siswa bahwa model pembelajaran Problem Based Learning harus lebih menarik dan lebih menyenangkan agar siswa tidak merasa bosan.

Dari tindakan siklus I, terdapat temuan yang diperoleh dari hasil belajar siswa, yaitu hasil belajar siswa belum maksimal. Pada kegiatan pembelajaran IPA siklus I, sebagian siswa masih banyak yang belum memahami penjelasan dari guru, sehingga untuk hasil belajar siswa kurang diperhatikan. Tindakan siklus I, dari 20 siswa masih ada 7 siswa yang belum tuntas karena mendapat nilai dibawah $\geq 70$ yaitu sekitar $65 \%$. Dari refleksi tindakan siklus I, peneliti akan mengembangkan pengetahuan yang telah diperoleh selama kegiatan pembelajaran, dan perbaikan pada rencana pelaksanaan pembelajaran (RPP) di siklus II.

Tindakan pada siklus II dianggap pada tindakan terbaik yang telah dilakukan oleh peneliti. Adapun hal-hal yang dilakukan dalam rangka memperbaiki kekurangan kekurangan pada siklus I adalah : (1) Siswa tidak memiliki keberanian untuk tampil di depan kelas untuk mambacakan hasil diskusinya; (2) Siswa banyak yang bermain dan tidak memperhatikan penjelasan guru; (3) Siswa kurang mampu menyampaikan alasan logis susunan model pembelajaran Problem Based Learning (PBL); (4) Siswa masih kurang dalam melakukan percobaan. Kegiatan refleksi yang dilakukan antara peneliti dan guru pada tindakan siklus II ternyata hasil pembelajaran telah menunjukkan hasil yang menggembirakan baik bagi guru mata pelajaran maupun bagi peneliti meskipun ada beberapa kelemahan dan kekurangan yang masih ditemukan pada tindakan siklus II untuk memperbaiki kelemahan yang didapat pada tindakan silus I maka dilanjutkan pada siklus II, sudah mendapat hasil yang maksimal karena indikator keberhasilan telah tercapai dengan baik. Pada pelaksanaan tindakan siklus II, proses pembelajaran dalam meningkatkan hasil belajar siswa mengalami peningkatan yang signifikan yaitu dari 20 siswa, yang telah tuntas adalah 18 siswa atau sebesar 90\% dan telah mencapai indikator keberhasilan $\geq$ 70 .

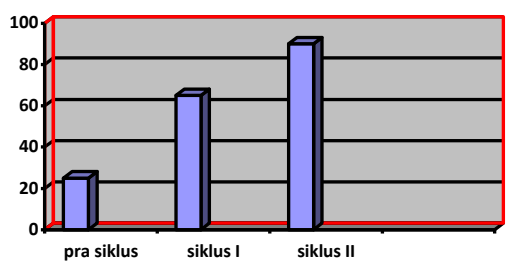

\section{Gambar 2. Perbandingan hasil belajar pra siklus, siklus I dan siklus II}

Pada hasil observasi aktivitas guru siklus I secara menyeluruh terdapat 2 kriteria yang tidak dilaksanakan oleh guru, yaitu melaksanakan pembelajaran secara runtut, dan melaksanakan pembelajaran sesuai dengan waktu yang telah dialokasikan. Proses pembelajaran hendaknya dilaksanakan secara runtut sesuai skenario pembelajaran yang telah ditentukan supaya kegiatan pembelajaran 
berjalan dengan efektif dan tujuan pembelajaran akan tercapai. Secara umum kegiatan pembelajaran sudah berlangsung cukup baik. Sedangkan untuk siklus II aktivitas guru dalam proses pembelajaran yang diamati sudah dilaksanakan oleh guru, yaitu mulai dari kegiatan awal, kegiatan inti dan penutup. Pada siklus II ini proses pembelajaran sudah berlangsung dengan baik sesuai perencanaan pembelajaran. Hasil ini menunjukkan peningkatan aktivitas performansi guru dalam proses pembelajaran.

Berdasarkan hasil pelaksanaan tindakan awal (pra siklus), siklus I maupun siklus II yang mengalami peningkatan dalam pembelajaran IPA materi Perubahan Lingkungan maka dapat disimpulkan bahwa penggunaan model pembelajaran Problem Based Learning dapat meningkatkan hasil belajar siswa kelas IV SDN Kertosari I Kabupaten Madiun.

\section{E. KESIMPULAN DAN SARAN}

Berdasarkan paparan hasil penelitian tindakan kelas diatas, dapat disimpulkan bahwa pembelajaran IPA materi perubahan lingkungan melalui model pembelajaran Problem Based Learning (PBL) untuk siswa kelas IV SDN Kertosari I Kabupaten Madiun meningkat, yang dilaksanakan dua siklus dengan nilai yang diperoleh siswa pada pembelajaran sebelumnya (pra siklus), hasil tes siklus I dan siklus II dengan presentase pada pra siklus 25\%, pada siklus I yaitu 65\%, dan pada siklus II yaitu 90\% dari 20 siswa sehingga secara keseluruhan hasil belajar siswa sudah meningkat secara signifikan dan diatas KKM $\geq 70$.

Peningkatan tersebut meliputi peningkatan hasil belajar siswa dengan aspek kemampuasn siswa dalam memecahkan masalah, kemampuan siswa dalam melakukan percobaan, kerjasama dalam kelompok, peningkatan dilakukan sesuai dengan proses pembelajaran secara runtut sesuai skenario pembelajaran, membimbing siswa dalam diskusi, memberikan respon scara positif, melakukan refleksi untuk mengidentifikasi kekurangan dan kesulitan siswa dalam memecahkan masalah pada materi perubahan lingkungan dan memberikan pemantapan pemahaman pada materi perubahan lingkungan.

Dari kesimpulan diatas peneliti memberikan saran kepada guru, sekolah dan peneliti selanjutnya, sebagai referensi untuk penelitian selanjutnya yaitu sebagai berikut: Sebagai bahan masukan bagi guru untuk memilih model pembelajaran yang tepat dalam mengajar IPA, salah satunya adalah dengan menggunakan model pembelajaran Problem Based Lerning (PBL). Guru diharapkan selalu memberi bimbingan dan pengarahan kepada siswa, khususnya kepada siswa yang hasil belajar belum tuntas dan siswa yang kurang aktif di kelas. Guru diharapkan mampu menciptakan suasana pembelajaran yang bermakna dan menyenangkan serta membangun asumsi positif dalam pembelajaran IPA. Sekolah menerapkan salah satu aspek lingkungan yang memiliki peran dalam perkembangan anak. Sebaiknya sekolah memberikan 
fasilitas kepada guru untuk mengembangkan media pembelajaran yang inovatif, dan kreatif yang tidak hanya digunakan sebagai alternatif dalam pembelajaran IPA tetapi juga dapat digunakan mata pelajaran lainnya karena dapat meningkatkan keterampilan guru, aktivitas siswa, dan hasil belajar siswa.

Penelitian tindakan kelas ini diharapkan dapat menjadi kajian awal bagi penelitian serupa. Peneliti lain dapat mengembangkan penelitian ini dan melakukan perbandingan dengan pendekatan maupun model pembelajaran yang lebih bervariatif lainnya ataupun memodifikasi model ini sesuai dengan inovasi dan kondisi penelitian lainnya. Namun untuk model pembelajaran Problem Based Learning ini apabila diterapkan di dalam kelas tidak bisa berdiri sendiri dan masih menggunakan bantuan media pembelajaran, tetapi apabila di terapkan di luar kelas tidak perlu menggunakan alat bantu atau media pembelajaran karena sudah dihadapkan dengan permasalahan yang nyata.

\section{F. DAFTAR PUSTAKA}

Arikunto, Suharsimi. Prosedur Penelitian Suatu Pendekatan Praktek. Jakarta: Rineka Cipta, 2006.

Kusumawati, Naniek. "PENGEMBANGAN MEDIA PEMBELAJARAN IPA DENGAN ANIMASI MACROMEDIA FLASH BERBASIS MODEL PENGAJARAN LANGSUNG (DIRECT INSTRUCTION) DI SEKOLAH DASAR." Premiere Educandum: Jurnal Pendidikan Dasar Dan Pembelajaran 5, no. 02 (2016).

Rusman. Model-Model Pembelajaran Mengembangkan Profesionalisme
Guru. Jakarta: Raja Grafindo Persada, 2010.

Slameto. Belajar Dan Faktor-Faktor Yang Mempengaruhinya. Jakarta: Rineka Cipta, 1988.

Sudjana, Nana. Penilaian Hasil Proses Belajar Mengajar. Remaja Rosdakarya, 1990.

Suprijono, Agus. Cooperative Learning. Yogyakarta: Pustaka Pelajar, 2011.

Susanto, Ahmad. Teori Belajar Dan Pembelajaran Di Sekolah Dasar. Jakarta: Kencana Prenada Media Group, 2013.

Sutirman. Media Dan Model-Model Pembelajaran Inovatif. Yogyakarta: Graha Ilmu, 2013. 